\title{
Sensitivity of Ewing's sarcoma to TRAIL-induced apoptosis
}

\author{
HU Kontny ${ }^{\star, 1}$, K Hämmerle ${ }^{1}$, R Klein ${ }^{1}$, P Shayan ${ }^{1}$, \\ $\mathrm{CL}_{\text {Mackall }}{ }^{2}$ and $\mathrm{CM}$ Niemeyer ${ }^{1}$ \\ ${ }^{1}$ Children's Hospital of the Albert-Ludwigs-University, Freiburg, Germany \\ 2 Pediatric Oncology Branch, National Cancer Institute, Bethesda, MD, USA \\ * Corresponding author: HU Kontny, Children's Hospital of the Albert-Ludwigs- \\ University, Mathildenstr. 1, 79106 Freiburg, Germany. Tel: 49-761-270-4506; \\ Fax: 49-761-270-4518; E-mail: kontny@kkl200.ukl.uni-freiburg.de
}

Received 14.3.00; revised 5.10.00; accepted 29.12.00

Edited by G Melino

\begin{abstract}
Tumor necrosis factor-related apoptosis-inducing ligand (TRAIL) is able to kill transformed cells. We have studied the expression and functionality of the TRAIL apoptotic pathway in Ewing's sarcoma. We demonstrate that tumors from patients with Ewing's sarcoma express receptors TRAIL-R1 and -R2. Using a panel of nine Ewing's sarcoma cell lines TRAIL could induce apoptosis in seven cell lines. Preincubation with interferon- $\gamma$ rendered the two resistant cell lines sensitive. TRAIL was the most potent inducer of apoptosis when compared to Fas ligand or TNF. TRAIL-mediated apoptosis could be inhibited by various caspase-inhibitors. No difference in the surface expression of TRAIL-receptors was observed between sensitive and resistant cell lines. Also, all cell lines had similar levels of expression of Flice-like inhibitory protein (FLIP) on immunoblot. However, the two resistant cell lines had only very low level expression of caspase 8 on RNA and protein level. In summary, we show that Ewing's sarcoma expresses receptors for TRAIL, and that cells are exquisitely sensitive to TRAIL-mediated apoptosis. These results may warrant clinical trials with TRAIL in Ewing's sarcoma once the safety of TRAIL for humans has been established. Cell Death and Differentiation (2001) 8, 506-514.
\end{abstract}

Keywords: Ewing's sarcoma; TRAIL; interferon- $\gamma$; caspase 8; apoptosis

Abbreviations: DEVD, Asp(OMe)-Glu-Val-Asp(OMe); ES, Ewing's sarcoma; FasL, Fas ligand; FLIP, FLICE-like inhibitory protein; fmk, fluoromethylketone; IETD, lle-Glu-Thr-Asp(OMe); IFN$\gamma$, interferon- $\gamma$; RT - PCR, reverse transcriptase-PCR; TNF, tumor necrosis factor; TRAIL, tumor necrosis factor-related apoptosisinducing ligand; VAD, Val-Ala-Asp(OMe); VDVAD, Val-Asp(OMe)Val-Ala-Asp(OMe); YVAD, Tyr-Val-Ala-Asp(OMe); Z, benzyloxycarbonyl

\section{Introduction}

Ewing's sarcoma (ES) accounts for the second most common bone tumor in children. ${ }^{1}$ Although the cell of origin of ES remains unclear, prevailing concepts hold that these tumors arise from genetic changes within primitive neuroectodermal tissues, which lead to clonal proliferation and a loss of differentiative capacity. ${ }^{2,3}$ Unfortunately, the prognosis for patients with large primary tumors or metastatic disease treated with conventional therapy is poor. ${ }^{4,5}$ Since it has been shown in a variety of tumors that chemo- and radiation therapy induce apoptotic mechanisms to cause cancer cell death, investigation of the apoptotic mechanisms in ES could lead to new effective means of therapy. ${ }^{6}$

Activation of death receptors of the TNF-receptor superfamily expressed on cell membranes, provides a specific mechanism to induce apoptosis. ${ }^{7}$ We have previously shown that ES cells express the Fas receptor on their surface. ${ }^{8}$ However, the majority of cell lines studied were either resistant to Fas-mediated apoptosis or required the simultaneous application of the protein-synthesis inhibitor cycloheximide. In addition, the therapeutic usefulness of the Fas-pathway is hampered by Fas-expression on hepatocytes that induces lethal hepatic apoptosis upon activation. $^{9}$

The TNF-related apoptosis-inducing ligand (TRAIL, also called Apo2L; ${ }^{10,11}$ ) can induce apoptosis by interaction with two receptors of the TNF-receptor superfamily, referred to as TRAIL-R1 (also called DR4; ${ }^{12}$ ) and TRAIL-R2 (also called DR5/TRICK-2/KILLER; ${ }^{13-19}$ ). Recent evidence suggests that TRAIL-induced apoptosis seems to utilize a pathway similar to the one used by FasL with recruitment of the adaptor molecule Fas-associated death domain protein (FADD) and subsequent activation of caspase $8^{20-22}$ TRAIL appears to be able to induce apoptosis in a wide range of transformed cell lines. ${ }^{10,11}$ The systemic application of TRAIL into mice has been shown to be nontoxic and able to suppress the growth of a human mammary adenocarcinoma. $^{23}$ The clinical usefulness of TRAIL, however, has to be evaluated carefully with respect to the recent finding that TRAIL can induce apoptosis in human hepatocytes upon in vitro culture. ${ }^{24}$

Resistance to TRAIL-mediated apoptosis is not fully understood. Protection of normal tissue from TRAILmediated apoptosis has been thought to be conferred by two additional receptors: TRAIL-R3 (also called DcR1/ TRID/LIT; ${ }^{13,14,18,19,25}$ ) and TRAIL-R4 (also called DcR2/ TRUNDD; ${ }^{26-28}$ ) which might either act as decoy receptors or provide inhibitory signals, such as activation of $\mathrm{NF}-\kappa \mathrm{B}$. Support for this hypothesis, however, has only come from experiments utilizing TRAIL-sensitive target cells transfected with either TRAIL-R3 and -R4 (reviewed $\mathrm{in}^{29}$ ). In contrast, in most tumor cell lines the expression of TRAILR3 and -R4 has not been shown to be associated with resistance to TRAIL. ${ }^{29,30}$ Resistance to TRAIL-induced apoptosis may also be regulated by the expression of intracellular inhibitory proteins such as cellular Flice-like inhibitory protein (FLIP). ${ }^{31,32}$ Recently, absent expression of caspase 8 has been shown to confer resistance to FasL 
and TRAIL-mediated apoptosis in neuroblastoma cell lines. ${ }^{33,34}$

To address the expression and functionality of the TRAIL-dependent pathway of programmed cell death in ES, we performed an analysis of the TRAIL system in tumors and in a series of ES cell lines.

\section{Results}

\section{Expression of TRAIL-receptors in ES tumors}

The expression of TRAIL-receptors was investigated in tumor samples from 10 patients with ES. Figure 1 demonstrates that mRNA for TRAIL-R1 is clearly expressed in eight of the 10 samples, and for TRAIL-R2 in all samples. Several tumor samples contain a second band for TRAIL-R1, which is shorter than the $674 \mathrm{bp}$ expected. This could be due to alternative splicing which has been reported for TRAILR1. ${ }^{12,14}$ Also, the non apoptosis-inducing receptors TRAIL$\mathrm{R} 3$ and $-\mathrm{R} 4$ are expressed in all tumor samples.

\section{The TRAIL-pathway is intact in ES}

In order to show the functionality of the TRAIL-pathway in ES, cell lines derived from tumors of patients with ES were incubated with recombinant human (rh) TRAIL. Apoptosis was determined via flowcytometry by propidium-iodide staining of subdiploid nuclei. Figure 2 a shows that $59 \%$ of cells of cell line RD-ES underwent apoptosis after 24-h incubation with $100 \mathrm{ng} / \mathrm{ml}$ of rh TRAIL. Studies on the kinetics of induction of apoptosis by TRAIL indicate that apoptosis could be detected after $12 \mathrm{~h}$ in two sensitive cell lines, SK-N$\mathrm{MC}$ and CHP-100 (Figure 2b). In contrast, in cell line JR no signs of apoptosis could be detected even after $24 \mathrm{~h}$. The susceptibility of ES cell lines was tested over a range of various concentrations of TRAIL. As shown in Figure 2c, apoptosis could already be detected between 50 and $100 \mathrm{ng} /$ $\mathrm{ml}$ in sensitive cell lines SK-N-MC and SB. Apoptosis of SK-N$\mathrm{MC}$ was maximal at $200 \mathrm{ng} / \mathrm{ml}$. In contrast, ES cell line JR was resistant even at rh TRAIL concentrations of $1000 \mathrm{ng} / \mathrm{ml}$.

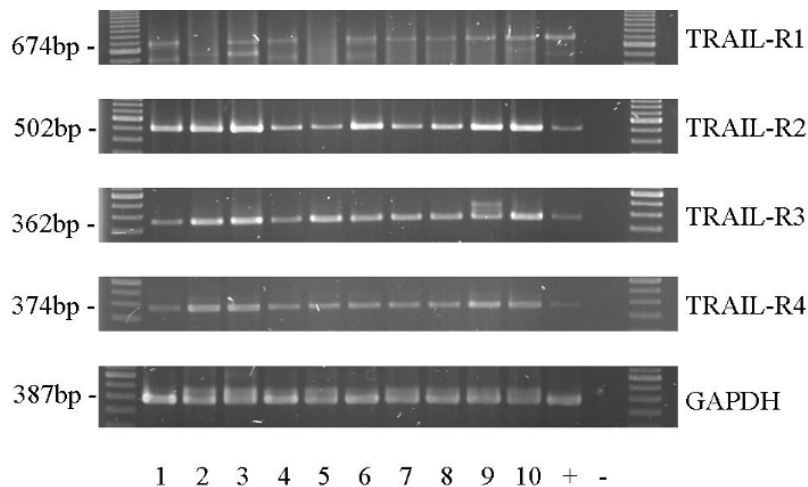

Figure 1 Expression of TRAIL-R1-R4 by RT-PCR in tumor samples of 10 patients with Ewing's sarcoma (1-10). Ewing's sarcoma cell line TC-71 was used as positive control (+), no RNA as negative control (-)
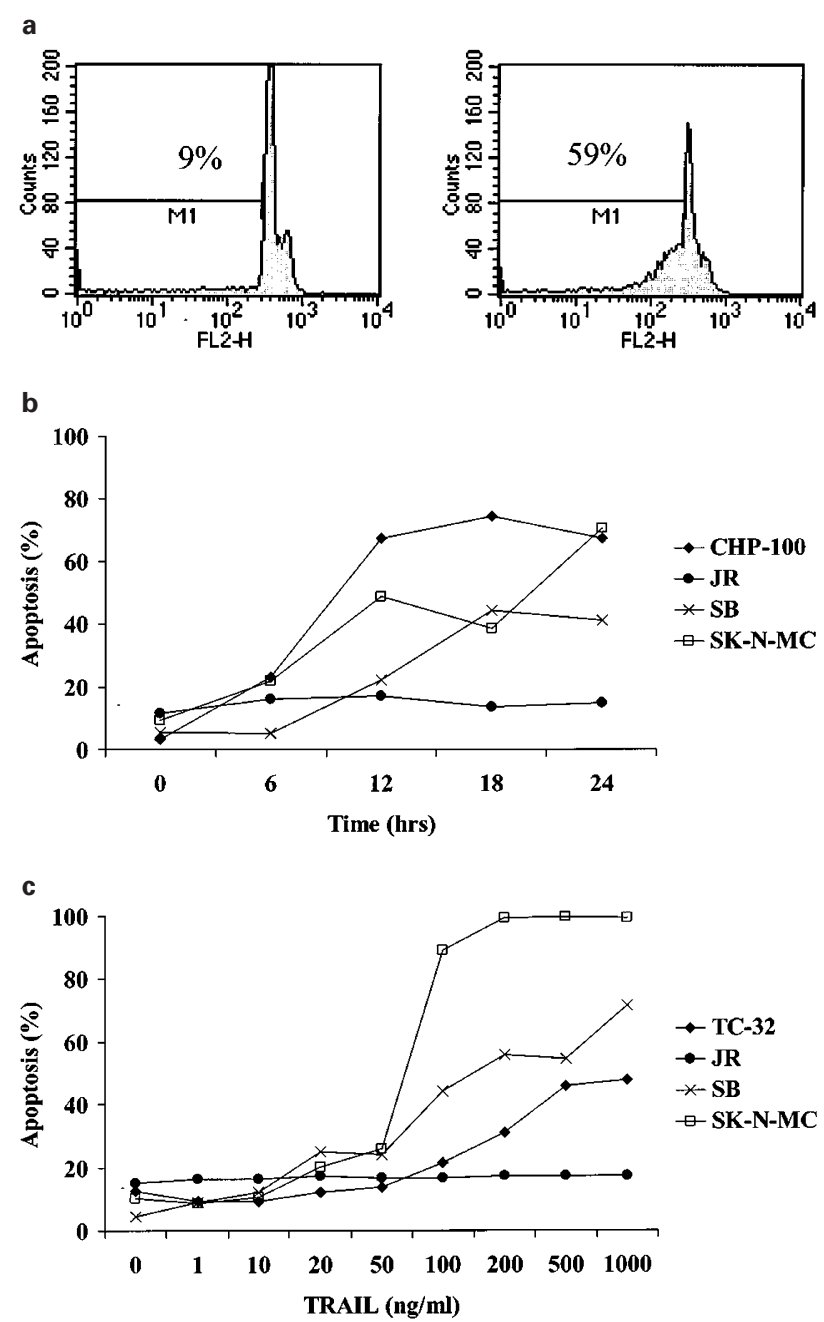

Figure 2 TRAIL induces apoptosis in Ewing's sarcoma cell lines. (a) Detection of apoptosis by flowcytometry of propidium iodide stained nuclei of cell line RD-ES after incubation with $100 \mathrm{ng} / \mathrm{ml}$ human recombinant TRAIL for $24 \mathrm{~h}$ (right); control (left). (b) Kinetics of induction of apoptosis by TRAIL at $200 \mathrm{ng} / \mathrm{ml}$ in ES cell lines CHP-100, JR, SB and SK-N-MC. (c) Titration of TRAIL against ES cell lines TC-32, JR, SB, and SK-N-MC

\section{The majority of ES cell lines are sensitive to apoptosis by TRAIL}

Figure 3a shows the sensitivity of a panel of nine ES cell lines towards apoptosis by TRAIL. Cells of seven of the nine cell lines can readily be killed by incubation with $100 \mathrm{ng} / \mathrm{ml} \mathrm{rh}$ TRAIL for $24 \mathrm{~h}$. This experiment was repeated on two occasions with similar results.

\section{IFN- $\gamma$ converts TRAIL-resistant ES cell lines to become sensitive}

We have previously shown that incubation with IFN- $\gamma$ and/or cycloheximide can convert some Fas-resistant ES cell lines to become Fas-sensitive. ${ }^{8}$ We therefore wanted to investigate whether the same effect could be observed in TRAILmediated apoptosis. IFN- $\gamma$ is thought to increase the 
susceptibility to Fas-mediated lysis in T-cells and a variety of tumor cell lines by upregulation of receptors for Fas and FasL and/or modulation of intracellular apoptotic pathways. ${ }^{35-38}$ Cycloheximide is thought to convert Fas-resistant cell lines to become Fas-sensitive by blockade of a short-lived inhibitor. ${ }^{39}$ In addition, cycloheximide has been shown to downregulate FLIP-protein expression in melanoma cell lines and this was associated with sensitization towards TRAIL. ${ }^{32}$ Figure $3 b$ demonstrates that the two TRAIL-resistant cell lines A4573 and JR could be converted to become sensitive to TRAILmediated apoptosis after preincubation with $2000 \mathrm{U} / \mathrm{ml}$ IFN- $\gamma$ for $60 \mathrm{~h}$. Interestingly, IFN- $\gamma$ by itself induced some apoptosis in these cell lines. Similar results were obtained in two independent repeats of the experiment. In contrast, concomitant treatment of cell lines with TRAIL and cycloheximide could not convert the two TRAIL resistant cell lines A4573 and JR to become TRAIL-sensitive, however, increased the percentage of apoptotic cells in most of the other cell lines (data not shown).

\section{Comparison of the TRAIL-pathway with the Fas- and TNFR-pathway}

Table 1 summarizes our results on the integrity of the TNFR-, Fas-, and TRAIL-pathway in the nine ES cell lines studied. All cell lines do have receptors for TNF and Fas ${ }^{8}$ (results not shown). Based upon a series of experiments a cutoff for apoptosis via death ligand was chosen with a percentage of cells with subdiploid DNA-content of $20 \%$ beyond the respective control level. Smaller differences with levels above the background level, which is up to $10 \%$ in untreated cells, might represent low positive findings. As demonstrated the TRAIL-pathway is superior to the other two pathways in inducing apoptosis. In the absence of additional treatment with IFN- $\gamma$ only RD-ES is sensitive to apoptosis induced by the anti-Fas antibody $\mathrm{CH}-11$. The level of induction of apoptosis in RD-ES by $\mathrm{CH}-11$ is stronger than the one we have published previously. ${ }^{8}$ This is most likely due to clonal variation, since the RD-ES cell

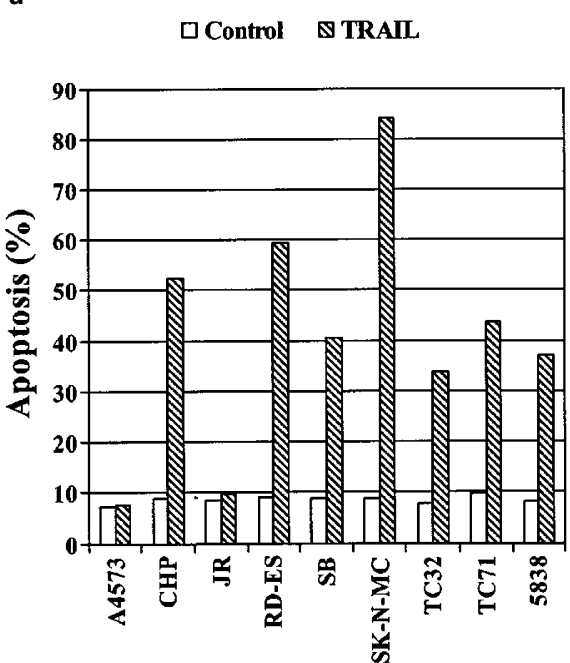

b

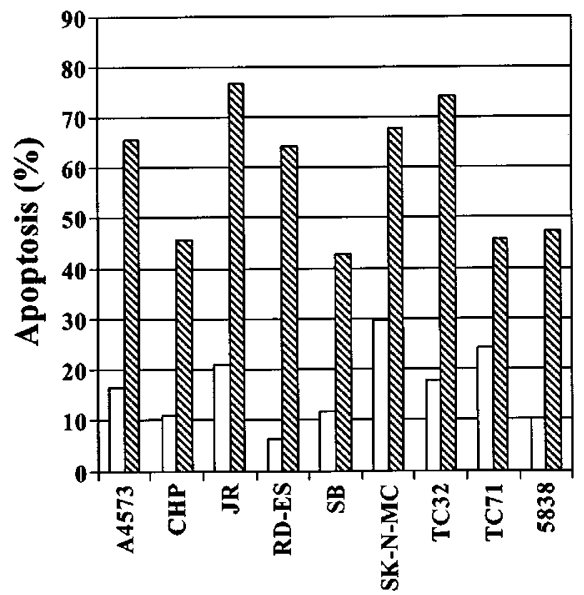

Figure 3 Sensitivity of nine Ewing's Sarcoma cell lines to apoptosis by TRAlL. Cell lines were treated with $100 \mathrm{ng} / \mathrm{ml}$ TRAlL for $24 \mathrm{~h}$. Apoptosis was assessed by flowcytometry. (a) Apoptosis induced by TRAIL alone. (b) ES cell lines were preincubated with $2000 \mathrm{U} / \mathrm{ml}$ recombinant IFN- $\gamma$ for $60 \mathrm{~h}$ and then treated with TRAIL as above. The same pattern was seen in three different experiments

Table 1 Induction of apoptosis via death receptors in Ewing's sarcoma cell lines

\begin{tabular}{|c|c|c|c|c|c|c|c|c|}
\hline \multirow[b]{2}{*}{ Cell line } & \multicolumn{4}{|c|}{$\%$ of Apoptosis induction without additional treatment ${ }^{a}$} & \multicolumn{4}{|c|}{$\%$ of Apoptosis induction with interferon- $\gamma^{\mathbf{b}}$} \\
\hline & Control & TRAIL & CH-11 & TNF & Control & TRAIL & CH-11 & TNF \\
\hline A4573 & 7 & 9 & 6 & 5 & 17 & 66 & 25 & 14 \\
\hline CHP-100 & 9 & 52 & 17 & 12 & 11 & 46 & 22 & 19 \\
\hline JR & 8 & 10 & 8 & 9 & 21 & 77 & 35 & 23 \\
\hline RD-ES & 9 & 59 & 77 & 5 & 6 & 64 & 81 & 5 \\
\hline SB & 9 & 41 & 6 & 8 & 12 & 43 & 13 & 24 \\
\hline SK-N-MC & 9 & 84 & 28 & 11 & 29 & 68 & 85 & 39 \\
\hline TC-32 & 8 & 34 & 5 & 4 & 18 & 74 & 28 & 14 \\
\hline TC-71 & 10 & 44 & 8 & 8 & 24 & 46 & 49 & 34 \\
\hline 5838 & 8 & 37 & 8 & 7 & 10 & 47 & 15 & 12 \\
\hline
\end{tabular}

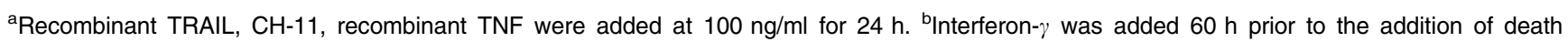
ligands 
line used in these studies was obtained from a different source than the one used before. Whereas all cell lines are susceptible to TRAIL after a $60 \mathrm{~h}$ preincubation with IFN- $\gamma$, only RD-ES, SK-N-MC, and TC-71 can be killed by $\mathrm{CH}-11$ under such conditions. Neither TNF alone nor in combination with IFN- $\gamma$ is able to induce apoptosis in any of the ES cell lines.

\section{TRAIL-mediated apoptosis is inhibited by a variety of caspase-inhibitors}

Figure 4 shows that TRAIL-mediated apoptosis can be inhibited by caspase-inhibitors and therefore must involve the activation of caspases. The relative sensitivity to various inhibitors, with Z-VAD-fmk being the most potent, and Z-VDVAD-fmk the least effective, is similar, if apoptosis is induced by TRAIL alone or by TRAIL and cycloheximide. In the presence of cycloheximide higher concentrations of caspase-inhibitors are needed to block apoptosis, suggesting that at least in some ES cell lines a short lived inhibitor, such as FLIP might play a regulatory role.

\section{Resistance to TRAIL-mediated apoptosis is not associated with differential expression of TRAIL-receptors between sensitive and resistant ES cell lines}

In order to investigate the mechanism of resistance of the two TRAIL-resistant cell lines A4573 and JR, ES cell lines were analyzed for the expression of receptors TRAIL-R1-R4 by RT - PCR and flowcytometry. Messenger RNA for TRAIL-R1 and $-\mathrm{R} 2$ could be clearly detected in seven and nine of the nine ES cell lines, respectively. Messenger RNA for the non apoptosis-inducing receptors TRAIL-R3 and -R4 could be demonstrated in nine and six out of nine ES cell lines (Figure 5a). By flowcytometry both resistant cell lines expressed TRAIL-R1 and -R2 on the surface to a similar level as did sensitive cell lines (Figure 5b). Surface expression of TRAIL$\mathrm{R} 3$ and -R4 was barely detectable in resistant as well as in sensitive cell lines.

\section{Expression of FLIP in sensitive and resistant cell lines}

Expression of the intracellular inhibitor FLIP has been shown to confer resistance to FasL and TRAIL-mediated apoptosis. ${ }^{31,32}$ We therefore studied the expression of FLIP in our panel of ES cell lines by RT-PCR and immunoblot. All nine ES cell lines expressed mRNA for FLIP (Figure 6a). FLIPprotein expression was also found in all nine cell lines, and there was no difference in the level of expression between sensitive and resistant cell lines (Figure 6b).

\section{Resistance to TRAIL-mediated apoptosis is associated with low-level expression of caspase 8}

Because TRAIL-mediated apoptosis involves the activation of caspases (reviewed $\mathrm{in}^{29}$ ) we investigated, whether differences in the expression of caspases were associated with resistance to TRAIL. RNase protection assay was used to screen for the mRNA expression of caspases 110. As shown in Figure 7a, both resistant cell lines A4573 and JR only showed very low level expression of caspase 8, whereas all sensitive cell lines clearly expressed mRNA for caspase 8. This could be confirmed on protein level, with strong expression of caspase 8 by all sensitive cell lines and only very faint expression by the two resistant cell lines (Figure $7 \mathrm{~b}$ ).

\section{Discussion}

The data presented address the expression and functional status of the TRAIL system in ES, using tumor samples and a panel of nine ES cell lines. Our results show that all tumor samples from patients with ES express TRAIL-R2 and $80 \%$ express TRAIL-R1.

In order to investigate the functionality of the TRAILpathway in ES we used ES cell lines in which we have previously characterized the Fas/Fas ligand pathway. ${ }^{8}$ Our results show that apoptosis can be readily induced by TRAIL in seven out of nine cell lines. This is in contrast to results in breast cancer and tumors of hematological origin
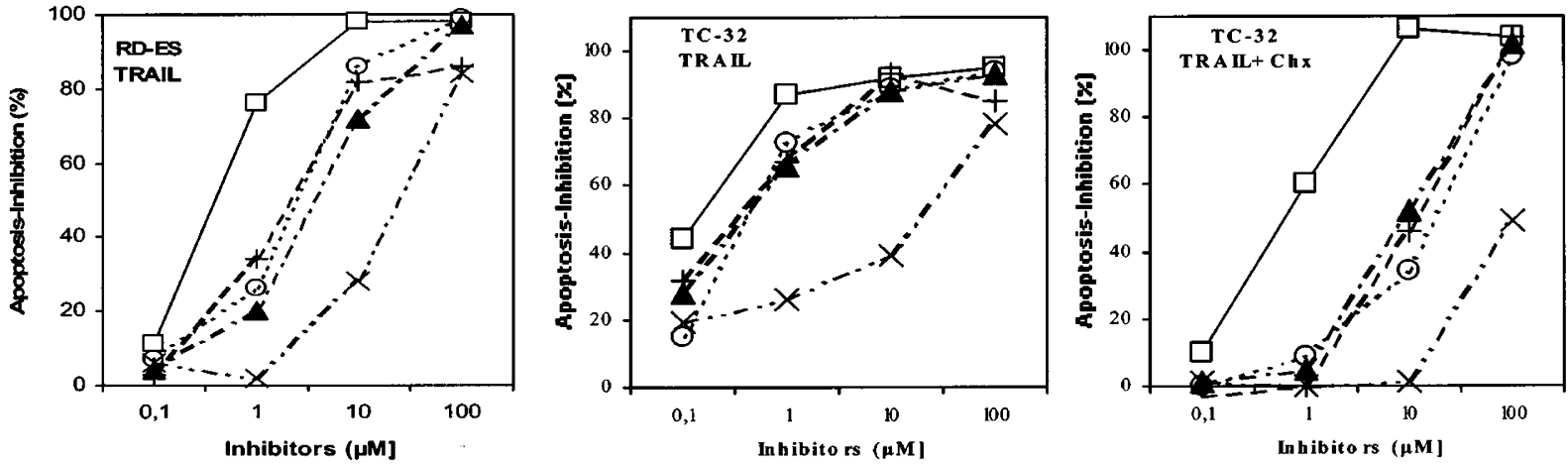

Figure 4 Inhibition of apoptosis by caspase-inhibitors in Ewing's sarcoma cell lines RD-ES and TC32. Cell lines were treated as indicated with 200 ng/ml TRAIL alone or concomitantly treated with $1 \mu \mathrm{g} / \mathrm{ml}$ cycloheximide. Thirty minutes prior to the addition of TRAIL, caspase-inhibitors were added at indicated concentrations. $\square$, Z-VAD-fmk; $x$, Z-VDVAD-fmk; $\boldsymbol{\Delta}$, Z-DEVD-fmk; O, Z-YVAD-fmk; +, Z-IETD-fmk 


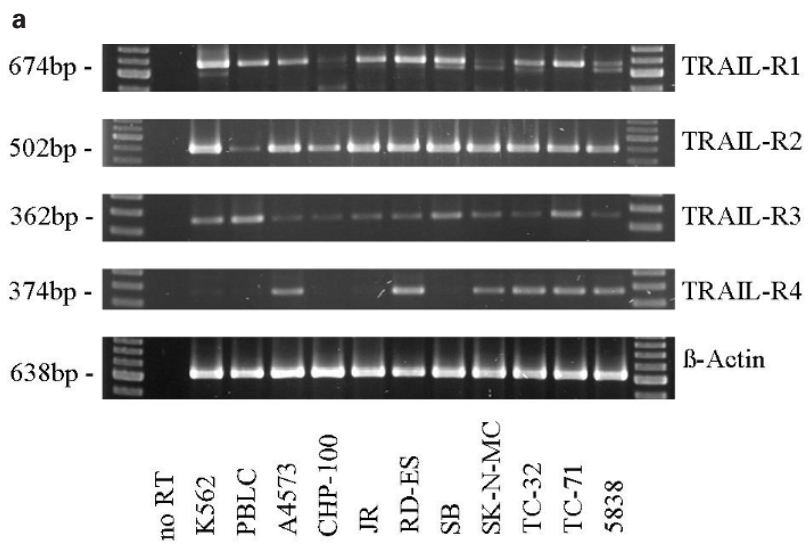

b

TRAIL-R1
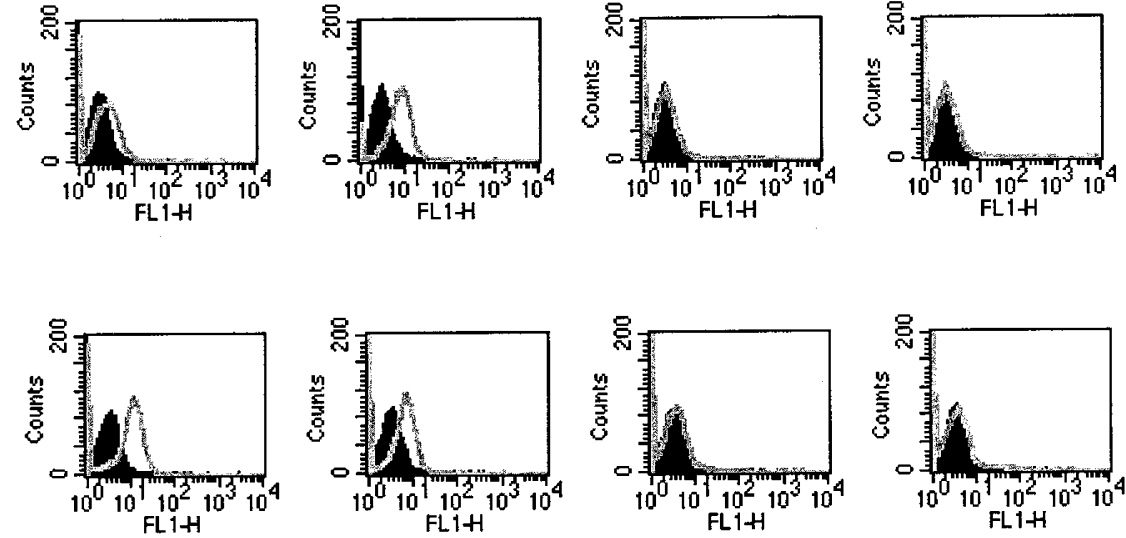

A4573
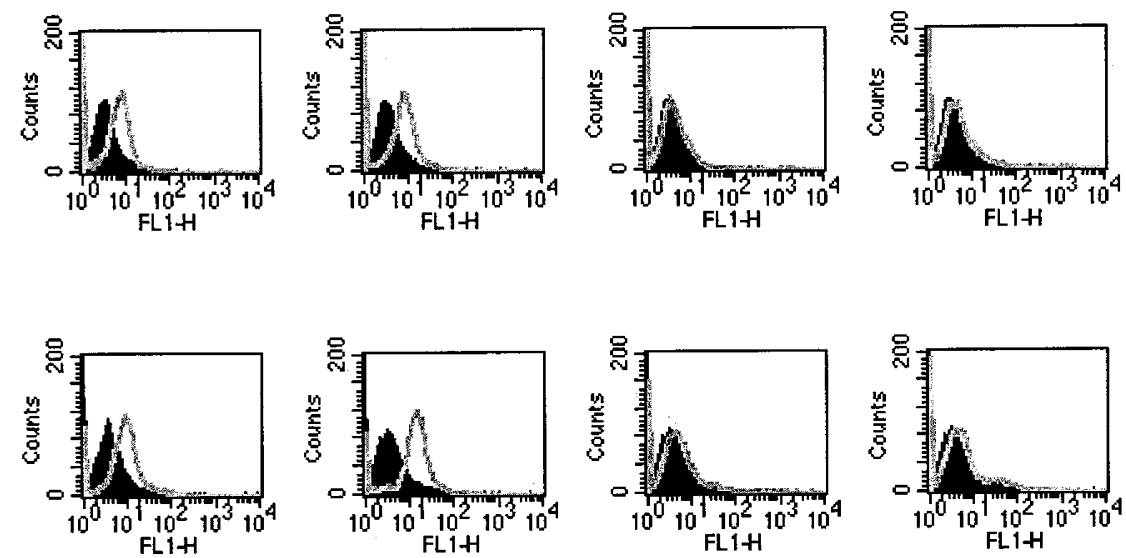

Figure 5 (a) Expression of TRAIL receptors in ES cell lines by RT - PCR. Cell line K562 and PBLC were used as controls. (b) Flowcytometric analysis of surface expression of TRAIL-receptors R1-R4 in TRAIL-sensitive cell lines TC-32 and TC-71, and TRAIL-resistant cell lines A4573 and JR. The open curves represent staining with the respective anti-TRAIL-antibody, the filled curves staining with an isotype control antibody

in which only $12.5 \%$ and $27 \%$ of tumors are killed by TRAIL, respectively. ${ }^{40,41}$ So far, melanoma cells have been shown to be the most sensitive target of apoptosis via TRAIL. ${ }^{30,32,42}$ Zhang et al. $^{30}$ could induce apoptosis by TRAIL in 19 out of 28 melanoma cell lines. Five of the sensitive cell lines showed, however, less than 20\% apoptotic cells after $24 \mathrm{~h}$. Interestingly, melanoma is also thought to be a tumor of neuroectodermal origin as is ES. ${ }^{43}$ Therefore, the sensitivity of both neoplasms to TRAILmediated apoptosis might be due to conservation of similar 


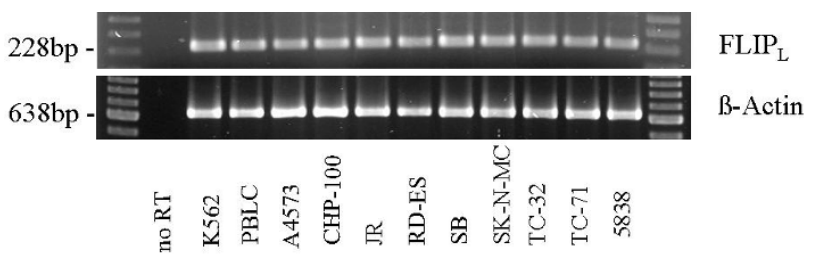

b

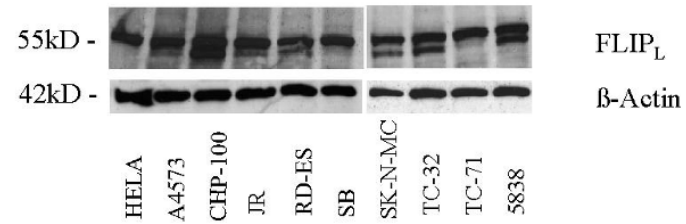

Figure 6 Expression of FLIP in ES cell lines. (a) Expression of FLIP $P_{L} m R N A$ by RT-PCR analysis. All nine ES lines expressed FLIP $\mathrm{L}_{\mathrm{L}} \mathrm{mRNA}$. $\beta$-Actin is included as a positive control. (b) Detection of a $M_{r} 55 \mathrm{kD}$ protein by immunoblot corresponding to $F L I P_{L}$. Similar level of expression of FLIP $P_{L}$ is seen in all nine cell lines. $\beta$-Actin is included as a loading control

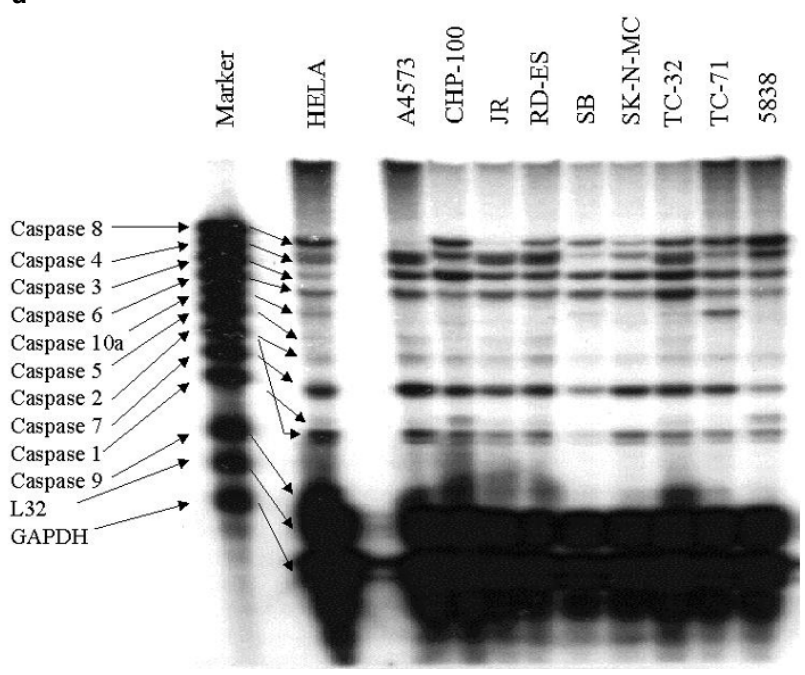

b $-55 \mathrm{kD}$

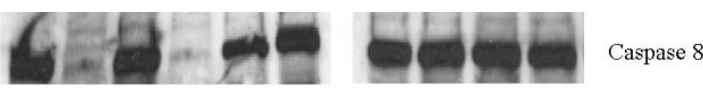

$-42 \mathrm{kD}$

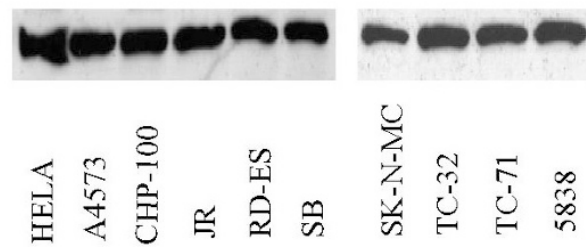

Figure 7 Expression of caspases in ES cell lines. (a) RNase protection assay for caspases 1-10. The probe lane represents antisense RNA probes before hybridization with RNA. House keeping genes L32 and GAPDH serve as normalized controls. Hela cells were included as a control. The resistant cell lines A4573 and JR have very low level of expression of caspase 8 when compared to the seven sensitive cell lines. (b) Expression of caspase 8 by immunoblot. Very low level expression of the two isoforms of caspase 8 is seen in the resistant cell lines A4573 and JR compared to the sensitive cell lines. $\beta$-Actin is included as a loading control apoptotic pathways in this group of tumors. It would be of interest to know whether other tumors of neuroectodermal origin such as retinoblastoma or small cell lung cancer will share this sensitivity.

Incubation with cycloheximide was unable to overcome resistance to TRAIL in the cell lines JR and A4573, but was able to augment the percentage of apoptotic cells in most of the sensitive cell lines (data not shown). Whereas no sensitizing effect of cycloheximide on TRAIL-mediated apoptosis has been described in breast cancer, cycloheximide and actinomycin D, another protein synthesis inhibitor, have been able to render resistant melanoma cells to become sensitive and increase the percentage of apoptotic cells in sensitive cell lines. ${ }^{32,41,42}$ This acquisition of TRAIL-sensitivity in melanoma has been shown to correlate with downregulation of FLIP, a known inhibitor of Fas ligand and TRAIL-mediated apoptosis. ${ }^{32}$

In contrast, preincubation of cell lines JR and A4573 with IFN- $\gamma$ rendered the cell lines sensitive to apoptosis by TRAIL. We have previously shown that preincubation with interferon- $\gamma$ sensitizes ES cell lines to FasL-mediated apoptosis and that this was only in one case associated with upregulation of Fas, suggesting modulation of downstream genes in a proapoptotic fashion. ${ }^{8}$ Whereas no effect of interferon- $\gamma$ on TRAIL-mediated apoptosis in tumor cells has been described, Sedger et al. ${ }^{44}$ showed that IFN- $\gamma$ increased the sensitivity of CMV-infected human fibroblast towards TRAIL-mediated apoptosis and that this was associated with downregulation of messenger RNA for TRAIL-R3 and -R4, induction of TRAIL, and downregulation of basal NF- $\kappa$ B activation. Further studies on the effect of IFN- $\gamma$ on apoptosis by TRAIL in ES are currently under way in our laboratory.

TRAIL-mediated apoptosis could be inhibited using different caspase-inhibitors. The same relative inhibition profile with Z-VAD-fmk being the most potent inhibitor and Z-VDVAD-fmk only conferring partial inhibition has been observed in Fas ligand-mediated apoptosis in prostatic carcinoma cell lines. ${ }^{45}$ In the presence of cycloheximide higher concentrations of caspase-inhibitors are needed to block apoptosis, suggesting higher level of caspase activation through the putative blockade of intracellular inhibitors, such as FLIP, by cycloheximide.

With regard to the potency of apoptosis via activation of death receptors, we show that TRAIL is the most effective ligand compared with Fas ligand or TNF. Interestingly, TRAIL alone is able to kill the Fas-resistant cell line SB. This cell line also shows resistance to adriamycin and etoposide in vitro (data not shown) and was derived from a patient with chemoresistant disease, suggesting that sensitivity to TRAIL may also exist in chemoresistant tumors.

In order to investigate whether resistance to TRAILmediated apoptosis was associated with differential expression of TRAIL-receptors, mRNA and surface expression of TRAIL-R1-R4 was examined. In melanoma, resistance of some cell lines to TRAIL has been shown to be due to the absence of both TRAIL-R1 and -R2. ${ }^{30}$ All of the ES cell lines studied expressed mRNA for TRAIL-R2 and -R3. Messenger RNA for TRAIL-R1 and -R4 was 
expressed in seven and six of the nine cell lines, respectively. Interestingly, resistant cell lines as well as sensitive cell lines expressed TRAIL-R1 and -R2 at similar levels on their surface, whereas the non apoptosis-inducing receptors TRAIL-R3 and -R4 were barely detectable. This suggests that resistance to TRAIL-mediated apoptosis in cell lines A4573 and JR is not regulated on the receptor level.

Expression of the intracellular inhibitor FLIP has also been shown to block TRAIL-mediated apoptosis. ${ }^{31,32}$ However, in our studies mRNA and protein expression of FLIP could be detected in all ES cell lines at similar levels. This suggests that expression of FLIP is not responsible for the resistance of cell lines A4573 and JR towards TRAIL, and also that FLIP is not able to suppress TRAIL-mediated apoptosis in sensitive Ewing's sarcoma cell lines. This is in contrast to work performed by Griffith in melanoma cell lines where the expression of FLIP on immunoblot correlated with resistance in a panel of eight cell lines. ${ }^{32}$ No correlation between expression of FLIP on mRNA and protein level and resistance to TRAIL was found in a larger study including 28 melanoma cell lines. ${ }^{30}$ However, in the latter study FLIP was detected by flowcytometric analysis of permeabilized cells, whereas in the study by Griffith the more sensitive immunoblotting was used. ${ }^{32}$ Some role for FLIP in Ewing's sarcoma, however, is suggested by our previous results that most cell lines required incubation with cycloheximide in order to sensitize them to apoptosis via the Fas-pathway. ${ }^{8}$

Recently, silencing of caspase 8 has been shown to be associated with resistance to Fas $L$ and TRAIL-mediated apoptosis in neuroblastoma. ${ }^{33,34}$ Caspase 8 has been shown to be recruited to the native TRAIL death-inducing signaling complex, and caspase 8-deficient Jurkat cells are resistant to TRAIL-mediated apoptosis. ${ }^{20-22}$ Transfection of caspase 8 into neuroblastoma cell lines with no caspase 8 expression restored their sensitivity versus death receptormediated apoptosis. ${ }^{33}$ Both resistant ES sarcoma cell lines showed very low expression of caspase 8 on RNA and protein level when compared to sensitive cell lines. These results suggest that resistance to TRAIL-mediated apoptosis in ES may be conferred by loss of expression or low level expression of caspase 8 , similar to neuroblastoma. With regard to clarifying the role of IFN- $\gamma$ in sensitizing resistant cell lines A4573 and JR to apoptosis by TRAIL, we have preliminary evidence that IFN- $\gamma$ can upregulate the expression of caspase 8 and other caspases in these cell lines. Further experiments to prove that the mechanism of sensitization by IFN- $\gamma$ is due to upregulation of caspase 8 are currently performed in our laboratory.

In summary, our results demonstrate that ES cells express receptors for TRAIL, and that the ES cell lines tested are exquisitely sensitive towards TRAIL-mediated apoptosis. Resistance to TRAIL-mediated apoptosis could be associated with low level expression of caspase 8 . In addition, TRAIL resistant cell lines could be sensitized by preincubation with IFN- $\gamma$. These results warrant further studies of TRAIL in ES and the inclusion of patients with ES into clinical trials with TRAIL, once safety of TRAIL in humans has been established.

\section{Material and Methods}

\section{Cells and cell lines}

Biopsy samples from 10 patients with ES were frozen in liquid nitrogen after informed consent had been obtained. ES cell lines A4573, CHP100, JR, SK-N-MC, TC-32, TC-71, and 5838 were kindly provided by Dr. Jeff Toretsky (Pediatric Oncology Branch, National Cancer Institute, Bethesda, MD, USA). The ES cell line RD-ES was obtained from the American Type Culture Collection (Rockville, MD, USA). All cell lines have been characterized previously. ${ }^{8,43,46-49}$ They were maintained in RPMl supplemented with $10 \%$ FCS and 100 units $/ \mathrm{ml}$ penicillin, $100 \mu \mathrm{g} / \mathrm{ml}$ streptomycin, and $4 \mathrm{mM}$ glutamine.

\section{Reagents}

Rh TRAIL and a cross-linking anti-TRAIL antibody were obtained from Alexis (Grünberg, Germany). The apoptosis-inducing anti-Fas-antibody, clone $\mathrm{CH}-11$, was purchased from Immunotech (Marseilles, France), human TNF from Sigma (Deisenhofen, Germany). The polyclonal rabbit anti-FLIP $P_{\mathrm{L}}$-antibody was purchased from Alexis, the mouse-anti-Caspase 8 antibody was kindly provided by $Y$ Lazebnik (Cold Spring Harbor Laboratories, Cold Spring Harbor, NY, USA). Goat-anti-rabbit and anti-mouse antibodies were purchased from Santa Cruz (Heidelberg, Germany). IFN- $\gamma$ was obtained from the $\mathrm{NCl}$ (Frederick, MD, USA). The mAbs against TRAIL-R1 (IgG2a huTRAILM271, Lot 7136-77), TRAIL-R2 (IgG1 huTRAIL-R2-M413, Lot 713688), TRAIL-R3 (IgG1 huTRAIL-R3-M430, Lot 7136-85), TRAIL-R4 (huTRAIL-R4-M444, Lot 7136-86) were kindly supplied by Immunex (Seattle, WA, USA). Isotype control mouse mAbs used were antiCD1a (IgG2a) and anti-CD3 (IgG1) from DAKO (Hamburg, Germany).

\section{RNA analysis and RT-PCR}

Frozen tumor samples from patients with ES were thawed in the PeqGOLDTrifast reagent containing guanidine isocyanate and phenol/ chloroform (Peqlab, Erlangen, Germany). Samples then were homogenized using a tissue homogenizer. Total RNA from homogenized tissue as well as from cell lines was prepared according to the manufacturer's instruction. First strand cDNAs were synthesized from $1 \mu \mathrm{g}$ of total RNA in $20 \mu \mathrm{l}$ reactions using random primers in the presence or absence of reverse transcriptase (Life Technologies, Karlsruhe, Germany). First strand cDNA ( $1 \mu \mathrm{l})$ was amplified using Taq polymerase (Life Technologies) in a $100 \mu$ reaction volume. The genespecific primers for TRAIL-R1, TRAIL-R2, and FLIP have been published previously. ${ }^{30,50}$ For amplification of TRAIL-R3 and R4, the following primers were constructed: TRAIL-R3 sense: AGTCCAAGTCAGTAATTGTAC, antisense: TCAGAAGCACAATTAGAACTATGA; TRAIL-R4 sense: GCTGACATCAGCACCTTGCTGGAT, antisense: ATGCAGCCAAGAATCTGATA. Samples were amplified for 35 cycles using the PCRExpress thermal sequencer (Hybaid, Heidelberg, Germany). The program consisted of one cycle at $94^{\circ} \mathrm{C}$ for $2 \mathrm{~min}$ and $95^{\circ} \mathrm{C}$ for $1 \mathrm{~min}$; 35 cycles of denaturation for $45 \mathrm{~s}$ at $95^{\circ} \mathrm{C}$, annealing for $45 \mathrm{~s}$ at $54^{\circ} \mathrm{C}$, and extension for $60 \mathrm{~s}$ at $72^{\circ} \mathrm{C}$; and finally $10 \mathrm{~min}$ at $72^{\circ} \mathrm{C}$. Samples were analyzed on a $0.5 \%$ agarose Trisacetate-EDTA gel stained with ethidium bromide.

\section{RNase protection assay}

A RiboQuant Multi-Probe RNase Protection Assay System (Pharmingen, Hamburg, Germany) was used per manufacturer's instructions. An hAPO5c probe set containing DNA templates for caspases 1-10, L32 and glyceraldehyde-3-phosphatase dehydrogenase (GAPDH) was used for T7 polymerase direct synthesis of $\left[\alpha^{32}\right.$-P]UTP-labeled 
antisense RNA probes. The probes were hybridized with $5 \mu \mathrm{g}$ of RNA of the above described ES cell lines. Samples were then digested with RNase to remove single-stranded (nonhybridized) RNA. Remaining probes were resolved on denaturing $5 \%$ polyacrylamide gels.

\section{Flow cytometric analysis}

Adherent cells were removed by trypsinization in $0.25 \%$ trypsin at $37^{\circ} \mathrm{C}$ for 5 min, washed once in RPMI supplemented with $10 \%$ FCS and twice in FACS-buffer (PBS containing $2 \%$ BSA). Two $\mu \mathrm{g}$ of mab against TRAIL-receptors or respective isotype controls were added per $5 \times 10^{5}$ cells and incubated at $4^{\circ} \mathrm{C}$ for $30 \mathrm{~min}$. Cells were washed twice with FACS-buffer and incubated for 30 min at $4^{\circ} \mathrm{C}$ with FITCconjugated goat anti-mouse Ig (Becton Dickinson, Heidelberg, Germany). After washing twice in FACS-buffer, cells were immediately analyzed on a FACScan analyzer (Becton Dickinson). A minimum of 10000 cells were analyzed.

\section{Immunoblots}

Protein was extracted from cells by detergent lysis using a buffer containing $10 \%$ SDS. The lysate was boiled for $10 \mathrm{~min}$, and cellular debris was then removed by centrifugation (10 min at 14000 r.p.m.). The protein concentration then was measured using the Bio-Rad protein assay (Bio-Rad Laboratories, Munich, Germany). Forty $\mu \mathrm{g}$ of protein were boiled $10 \mathrm{~min}$ before loading on a $12 \%$ SDSpolyacrylamide gel. Proteins were transferred to nitrocellulose membranes and then blocked for $30 \mathrm{~min}$ in PBS containing $5 \%$ dry milk and $0,01 \%$ Twen (Sigma). Membranes were incubated with primary antibodies in blocking buffer, washed three times in PBS/ Tween, incubated for an additional 30 min with a secondary antibody conjugated to horseradish peroxidase at a 1:2000 dilution, washed three times with PBS/Triton, and then developed using enhanced chemiluminescense (Amersham, Braunschweig, Germany).

\section{Apoptosis}

Apoptotic cells were determined by the propidium iodide method. ${ }^{51}$ In brief, ES cells were adhered overnight in a 96-well plate (Falcon Microtest, Becton Dickinson) at a concentration of $1 \times 10^{5} /$ well in $10 \%$ FCS. The following morning TRAIL, $\mathrm{CH}-11$ or TNF were added the indicated concentrations. In the case of TRAIL, a crosslinking antiTRAIL-antibody at a final concentration of $2 \mu \mathrm{g} / \mathrm{ml}$ was added. When indicated cycloheximide (Sigma) was added at a final concentration of $1 \mu \mathrm{g} / \mathrm{ml}$ together with the death ligand, and IFN- $\gamma$ at a concentration of 2000 units $/ \mathrm{ml} 60 \mathrm{~h}$ before incubation with the death ligand. Twentyfour hours after addition of the specific death ligand, cells in suspension and adherent cells were collected in $12 \times 75 \mathrm{~mm}$ Falcon Polystyrene tubes and centrifuged at $200 \times g$. The cell pellet was resuspended in $400 \mu \mathrm{l}$ of a hypotonic buffer (propidium iodide, $50 \mu \mathrm{g} /$ $\mathrm{ml}, 0.1 \%$ sodium citrate plus $0.1 \%$ Triton $\mathrm{X}-100$ ) and placed at $4{ }^{\circ} \mathrm{C}$ in the dark overnight. Flowcytometric analysis was performed using a FACScan analyzer (Becton Dickinson). The propidium iodide fluorescence of individual nuclei was measured in the red fluorescence and the data registered in a logarithmic scale. At least $10^{4}$ cells of each sample were analyzed.

\section{Inhibition of apoptosis}

To investigate the role of different inhibitors in apoptosis, ES cell lines were incubated with five different cell-permeable inhibitors of caspases: Z-VAD-fmk, Z-VDVAD-fmk, Z-DEVD-fmk, Z-YVAD-fmk, and Z-IETD-fmk (all from RD-Systems, Wiesbaden, Germany). The inhibitors were added at the indicated concentrations 30 min prior to the addition of the death ligands.

\section{Acknowledgements}

We thank Dr. Paul Fish and Bernd Wassmer for technical support, Dr. Stan Lipkowitz for helpful discussion, and Dr. Lee Helman for reviewing the manuscript.

\section{References}

1. Horowitz ME, Malawer MM, Woo SY and Hicks MJ (1997) Ewing's sarcoma family of tumors: Ewing's sarcoma of bone and soft tissue and the peripheral neuroectodermal tumors. In Principles and Practice of Pediatric Oncology, Pizzo PA and Poplack DG, eds (Philadelphia: JB Lippincott Co.) pp. 831-863

2. Cavazzana AO, Miser JS, Jefferson J and Triche TJ (1987) Experimental evidence for a neural origin of Ewing's sarcoma of bone. Am. J. Pathol. 127: 507-511

3. Thiele CJ (1991) Biology of pediatric peripheral neuroectodermal tumors. Cancer Metastasis Rev. 10: 311-318

4. Horowitz ME, Kinsella TJ, Wexler LH, Belasco J, Triche T, Tsokos M, Steinberg SM, McClure L, Longo DL, Steis RG, Glatstein E, Pizzo PA and Miser JS (1993) Total body irradiation and autologous bone marrow transplantation in the treatment of high-risk Ewing's sarcoma and rhabdomyosarcoma. J. Clin. Oncol. 11: $1908-1911$

5. Paulussen M, Ahrens S, Burdach S, Craft A, Dockhorn-Dworniczak B, Dunst J, Frohlich B, Winkelmann W, Zoubek A and Jurgens H (1998) Primary metastatic (stage IV) Ewing tumor: survival analysis of 171 patients from the EICESS studies. European Intergroup Cooperative Ewing Sarcoma Studies. Ann. Oncol. 9: $275-281$

6. Fisher DE (1994) Apoptosis in cancer therapy: crossing the treshhold. Cell 78: $539-542$

7. Ashkenazi A and Dixit VM (1998) Death Receptors: Signaling and Modulation. Science (Washington DC) 281: 1305-1308

8. Kontny HU, Lehrnbecher TM, Chanock SJ and Mackall CL (1998) Simultaneous expression of Fas and non-functional Fas ligand in Ewing's sarcoma. Cancer Res. 58: $5842-5849$

9. Ogasawara J, Watanabe FR, Adachi M, Matsuzawa A, Kasugai T, Kitamura Y, Itoh N, Suda T and Nagata S (1993) Lethal effect of the anti-Fas antibody in mice. Nature (Lond.) 364: 808-809

10. Wiley SR, Schooley K, Smolak PJ, Din WS, Huang CP, Nicholl JK, Sutherland GR, Smith TD, Rauch C, Smith CA and Goodwin RG (1995) Identification and characterization of a new member of the TNF family that induces apoptosis. Immunity 3: 673-682

11. Pitti RM, Marsters SA, RuppertS, Donahue CJ, Moore A and Ashkenazi A (1996) Induction of apoptosis by APO-2 ligand, a new member of the tumor necrosis factor cytokine family. J. Biol. Chem. 271: 12687-12690

12. Pan G, O'Rourke K, Chinnaiyan AM, Gentz R, Ebner R, Ni J and Dixit VM (1997) The receptor for the cytotoxic ligand TRAIL. Science (Washington DC) 276: $111-113$

13. Pan G, Ni J, Wie YF, Gentz Rand Dixit VM (1997) An antagonistic decoy receptor and a death domain-containing receptor for TRAIL. Science (Washington DC) 277: $815-817$

14. Sheridan JP, Marsters SA, Pitti RM, Gurney A, Skubatch M, Baldwin D, Ramakrishnan L, Gray CL, Baker K, Wood WI, Goodard AD, Godowski P and Ashkenazi A (1997) Control of TRAIL-induced apoptosis by a family of signaling and decoy receptors. Science (Washington DC) 277: 818-820

15. Screaton GR, Mongolsapaya J, Xu XN, Cowper AE, McMichael AJ and Bell JI (1997) TRICK2, a new alternatively spliced receptor that transduces the cytotoxic signal from TRAIL. Curr. Biol. 7: 693-696

16. Walczak H, Degli-Esposti MA, Johnson RS, Smolak PJ, Waugh JY, Boiani N, Timour MS, Gerhardt MJ, Schooley KA, Smith CA, Goodwin RG and Rauch CT (1997) TRAIL-R2: a novel apoptosis-mediating receptor for TRAIL. EMBO J. 16: $5386-5397$ 
17. Wu GS, Burns TF, McDonald ER III, Jiang W, Meng R, Krantz ID, Kao G, Gan DD, Zhou JY, Muschel R, Hamilton SR, Spinner NB, Markowitz S, Wu G and El-Deiry WS (1997) KILLER/DR5 is a DNA-damage-inducible p53-regulated death receptor gene. Nat. Genet. 17: 141-143

18. MacFarlane M, Ahmad M, Srinivasula SM, Fernandes-Alnemri T, Cohen GM and Alnemri ES (1997) Identification and molecular cloning of two novel receptors for the cytotoxic ligand TRAIL. J. Biol. Chem. 272: 25417-25420

19. Schneider P, Bodmer JL, Thome M, Hofmann K, Holler N and Tschopp J (1997) Characterization of two receptors for TRAIL. FEBS Lett. 416: 329-334

20. Sprick MR, Weigand MA, Rieser E, Rauch CT, Juo P, Blenis J, Krammer PH and Walczak H (2000) FADD/MORT1 and caspase-8 are recruited to TRAIL receptors 1 and 2 and are essential for apoptosis mediated by TRAIL receptor 2 . Immunity 12: 599-609

21. Kischkel FC, Lawrence DA, Chuntharapai A, Schow P, Kim J and Ashkenazi A (2000) Apo2L/TRAIL-dependentrecruitment of endogenous FADD and caspase 8 to death receptors 4 and 5. Immunity 12: 611-620

22. Kuang AA, Diehl GE, Zhang J and Winoto A (2000)FADD is required for DR4- and DR5-mediated apoptosis. J. Biol. Chem. 275: 25065-25068

23. Walczak H, Miller RE, Ariail K, Gliniak B, Griffith TS, Kubin M, Chin W, Jones J, Woodward A, Le T, Smith C, Smolak P, Goodwin RG, Rauch CT, Schuh JCL and Lynch DH (1999) Tumoricidal activity of tumor necrosis factor-related apoptosisinducing ligand in vivo. Nature Med. 5: 157-163

24. Jo M, Kim TH, Seol DW, Esplen JE, Dorko K, Billiar TR and Strom S (2000) Apoptosis induced in normal human hepatocytes by tumor necrosis factorrelated apoptosis-inducing ligand. Nature Med. 6: 564-567

25. Degli-Esposti MA, Smolak PJ, Walczak H, Waugh J, Huang CP, DuBose RF, Goodwin RG and Smith CA (1997) Cloning and characterization of TRAIL-R3, a novel member of the emerging TRAIL receptor family. J. Exp. Med. 186: 11651170

26. Degli-Esposti MA, Dougall WC, Smolak JY, Waugh CA, Smith CA and Goddwin RG (1997) The novel receptor TRAIL-R4 induces NF- $k B$ and protects against TRAIL-mediated apoptosis, yet retains an incomplete death domain. Immunity 7 : $813-820$

27. Marsters SA, Sheridan JP, Pitti RM, Huang A, Skubatch M, Baldwin D, Yuan J, Gurney A, Goodard AD, Godowski Pand Ashkenazi A (1997) A novel receptorfor Apo2L/TRAIL contains a truncated death domain. Curr. Biol. 7: 1003-1006

28. Pan G, Ni J, Yu G, Wie YF and Dixit VM (1998) TRUNDD, a new member of the TRAIL receptor family that antagonizes TRAIL signalling. FEBS Lett. 424: 4145

29. Griffith TS and Lynch DH. TRAIL: a molecule with multiple receptors and contro mechanisms (1998) Curr. Opin. Immunol. 10: 559-563

30. Zhang XD, Franco A, Myers K, Gray C, Nguyen T and Hersey P (1999) Relation of TNF-related apoptosis-inducing ligand (TRAIL) receptor and FLICE-inhibitory protein expression to TRAIL-induced apoptosis of melanoma. Cancer Res. 59: $2747-2753$

31. Irmler M, Thome M, Hahne P, Schneider K, Hofman V, Steiner V, Bodmer J-L, Schroter M, Burns K, Mattmann C, Rimoldi D, French LE and Tschopp J (1997) Inhibition of death receptor signals by cellular FLIP. Nature (Lond.) 388: $190-$ 195

32. Griffith TS, Chin WA, Jackson GC, Lynch DH and Kubin MZ (1998) Intracellular regulation of TRAIL-induced apoptosis in human melanoma cells. J. Immunol. 161: $2833-2840$

33. Teitz T, Wie T, Valentine MB, Vanin EF, Grenet J, Valentine VA, Behm FG, Look AT, LahtiJM and Kidd VJ (2000) Caspase 8 is deleted or silenced preferentially in childhood neuroblastomas with amplification of MYCN. Nature Med. 6:529-535

34. Hopkins-Donaldson S, Bodmer JL, Bourloud KB, Brognara CB, Tschopp J and Gross N (2000) Loss of caspase-8 expression in highly malignant human neuroblastoma cells correlates with resistance to tumor necrosis factor-related apoptosis-inducing ligand-induced apoptosis. Cancer Res. 60: 4315-4319
35. Ossina NK, Cannas A, Powers VC, Fitzpatrick PA, Knight JD, Gilbert JR, Shekhtman EM, Tomei D, Umansky SR and Kiefer MC (1997) Interferon-gamma modulates p53-independent apoptotic pathway and apoptosis-related gene expression. J. Biol. Chem. 272: 16351-16357

36. Keane MM, Ettenberg SA, Lowey GA, Russell EK and Lipkowitz S (1996) Fas expression and function in normal and malignant breast cell lines. Cancer Res. 56: $4791-4798$

37. Weller M, Frei K, Groscurth P, Krammer PH, Yonekawa Y and Fontana A (1994) Anti-Fas/APO-1 antibody-mediated apoptosis of cultured human glioma cells. Induction and modulation of sensitivity by cytokines. J. Clin. Invest. 94: 954-964

38. Xu X, Fu XY, Plate J and Cheung AS (1998) IFN- $\gamma$ induces cell growth inhibition by Fas-mediated apoptosis: requirement of STAT1 protein for upregulation of Fas and FasL expression. Cancer Res. 58: 2832-2837

39. Arscott PL, Knapp J, Rymaszewski M, Bartron JL, Bretz JD, Thompson NW and Baker Jr JR (1997) Fas (APO-1, CD95)-mediated apoptosis in thyroid cells is regulated by a labile protein inhibitor. Endocrinology 138: 5019-5027

40. Keane MM, Ettenberg S, Nau MM, Russel EK and Lipkowitz S (1999) Chemotherapy augments TRAIL-induced apoptosis in breast cell lines. Cancer Res. 59: 734-751

41. Snell V, Clodi K, Zhao S, Goodwin R., Thomas EK, Morris SW, Kadin ME, Cabanillas F, Andreef $M$ and Younes A (1997) Activity of TNF-related apoptosis inducing ligand (TRAIL) in haematological malignancies. Br. J. Haematol. 99: 618-624

42. Thomas WD and Hersey $P$ (1998) TNF-related apoptosis-inducing ligand (TRAIL) induces apoptosis in Fas ligand-resistant melanoma cells and mediates CD4 T cell killing of target cells. J. Immunol. 161:2195-2200

43. Shamamian P, Mancini M, KawakamiY, Restifo NP, Rosenberg SA and Topalian SL (1994) Recognition of neuroectodermal tumors by melanoma-specific Tlymphocytes: evidence of antigen sharing by tumors from the neural crest. Cancer Immunol. Immunother. 39: 73-83

44. Sedger LM, Shows DM, Blanton RA, Peschon JJ, Goodwin RG, Cosman D and Wiley SR (1999) IFN- $\gamma$ mediates a novel antiviral activity through dynamic modulation of TRAIL and TRAIL receptor expression. J. Immunol. 163: 920-926

45. Rokhlin OW, Glover RA and Cohen MB (1998) Fas-mediated apoptosis in human prostatic carcinoma cell lines occurs via activation of caspase-8 and caspase-7. Cancer Res. 58: 5870-5875

46. Yee D, Favoni RE, Lebovic GS, Lombana F, Powell DR, Reynolds CP and Rosen N (1990) Insulin-like growth factor I expression by tumors of neuroectodermal origin with the $t(11 ; 22)$ chromosomal translocation. A potential autocrine growth factor. Clin. Invest. 86: 1806-1814

47. Chen P, Lin HH and WeismaBE (1995) A functional analysis of tumor suppressor activity for peripheral neuroepitheliomas by monochromosome transfer. Oncogene 10: 577-588

48. Atzpodien J, Gulati SC, Shimazaki C, Buhrer C, Oz S, Kwon JH, Kolitz JE and Clarkson BD (1998) Ewing's sarcoma: ex vivo sensitivity towards natural and lymphokine-activated killing. Oncology 45: 437-443

49. Toretsky JA, Conell Y, Neckers L and Bhat NK (1993) Inhibition of EWS-FLI-1 fusion protein with antisense oligodeoxynucleotides. Biochem. Biophys. Acta 1172: $155-158$

50. Ribeiro P, Renard N, Warzocha K, Charlot C, Jeandenant L, Callet-Bauchu E, Coiffier B and Salles G (1998) CD40 regulation of death domains containing receptors and their ligands on lymphoma B cells. Br. J. Hematol. 103: 684-689

51. Nicholetti I, Migliorati G, Pagliacei MC, Grignani F and Riccardi C (1991) A rapid and simple method for measuring thymocyte apoptosis by propidium iodide staining and flowcytometry. J. Immunol. Methods 139: 271-279 